\title{
RELIABILITY OF TURKISH VERSIONS OF TWO DIFFERENT ORAL HEALTH INDEXES FOR EDENTULOUS GERIATRIC PATIENTS: A PILOT STUDY
}

\author{
DİşSİz GERİATRİK HASTALARDA İKİ FARKLI AĞIZ SAĞLIĞI İNDEKSİNİN TÜRKÇE \\ VERSİYONLARININ GÜVENİLİRLİĞİ: PİLOT ÇALIŞMA
}

\author{
Dr. Öğr. Üyesi Sezgi CİNEL ŞAHİN*
}

\author{
Makale Kodu/Article code: 4260 \\ Makale Gönderilme tarihi; 03.01.2020 \\ Kabul Tarihi: 28.05.2020 \\ DOI : $10.17567 /$ ataunidfd. 743930
}

Sezgi Cinel Şahin: ORCID ID: 0000-00001-7623-782X

\section{ABSTRACT}

Aim: This study aimed to evaluate the Turkish version of the Geriatric Oral Health Assessment Index (GOHAI-TR) and Oral Health Impact Profile for Edentulous (OHIP-EDENT-TR) in edentulous geriatric patients using a total prosthesis.

Material and Methods: Twelve items in GOHAI and 19 items in OHIP-EDENT were translated into Turkish using the backtranslation technique. A total of 32 complete edentulous geriatric participants answered the GOHAI-TR and OHIP-EDENT-TR indexes twice at two different times (first day and second week). The data obtained from both applications were used for reliability and test-retest analysis. Reliability was analyzed with Cronbach's alpha $(\alpha)$ and test-retest analyses were conducted using statistical software.

Results: The mean item score of GOHAI-TR was found to be higher, especially in terms of physical function negatively affecting the quality of life. Cronbach's $\alpha$ value of GOHAI-TR was found to be 0.897 and it any of the index items did not need to be removed. Similarly, the OHIP-EDENT-TR index showed that the most serious problems among participants were related to psychological discomfort, psychological and social disability, and also handicap. Cronbach's $\alpha$ value of OHIP-EDENT-TR was found to be 0.947 and it was determined that no item was required to be removed from the questionnaire.

Conclusion: The GOHAI-TR and OHIP-EDENT-TR indexes can be considered scales with excellent reliability and homogeneity for edentulous patients. Further studies are needed to elucidate different factors such as bone resorption degrees and period of edentulousness that may affect oral health and satisfaction in edentulous geriatric individuals.

Key words: Geriatric Dentistry; Geriatric Assessment; Edentulism; Complete Denture

\section{öz}

Amaç: Bu çalışmanın amacı, total protez kullanan dişsiz geriatrik hastalarda, Geriatrik Ağız Sağlığı Değerlendirme İndeksi (GOHAI-TR) ve dişsiz hastalar için Ağız Sağlığı Etki Profili (OHIP-EDENT-TR) indekslerinin Türkçe versiyonlarını değerlendirmektir.

Gereç ve Yöntem: 12 maddelik GOHAI ve 19 maddelik OHIP-EDENT indeksleri geri-çeviri tekniği kullanılarak Türkçe 'ye çevrildi. Toplam 32 tam dişsiz geriatrik katılımc GOHAI-TR ve OHIP-EDENT-TR anketlerini iki farklı zamanda (birinci gün ve ikinci hafta) iki kez yanıtladı. Her iki uygulamadan elde edilen veriler güvenilirlik ve test-tekrar test analizi için kullanıldı. Güvenilirlik Cronbach alfa $(\alpha)$ verileri ile analiz edilirken, test-tekrar test analizleri de istatistiksel yazılım kullanılarak yapıldı.

Bulgular: GOHAI-TR indeksi ortalama madde puanları, özellikle fiziksel işlev açısından yaşam kalitesini olumsuz yönde etkileyen sorularda daha yüksek bulundu. GOHAI-TR için Cronbach 's $(\alpha)$ değeri 0.897 olarak bulundu ve indeks maddelerinden herhangi birinin çıkartılmasına gerek olmadığı tespit edildi. Benzer şekilde, OHIP-EDENT-TR indeks katılımclarının en ciddi sorunlarının psikolojik rahatsızık, psikolojik ve sosyal yetersizlik ve handikap ile ilgili olduğu tespit edildi. OHIP-EDENT-TR için Cronbach 's $(\alpha)$ değeri 0,947 olarak bulundu ve anketten hiçbir maddenin çıkartılmasının gerekmediği tespit edildi.

Sonuç: Dişsiz bireyler için, GOHAI-TR ve OHIP-EDENT-TR indeksleri mükemmel güvenilirlik ve homojenlik sergileyen ölçekler olarak kabul edilebilir. Dișsiz ve yaşı bireylerde ağız sağlığı ve memnuniyetini etkileyebilecek alveolar kemik rezorpsiyon dereceleri ve dişsizlik süresi gibi farklı faktörleri de dikkate alan daha fazla çalışmaya ihtiyaç vardır.

Anahtar kelimeler: Geriatrik Diş Hekimliği; Geriatrik Değerlendirme, Dişsizlik; Tam Protez

\section{* Department of Prosthodontics, Faculty of Dentistry, Pamukkale University, 20160, Denizli}

Kaynakça Bilgisi: Şahin SC. Dişsiz Geriatrik Hastalarda İki Farklı Ağız Sağlığı İndeksinin Türkçe Versiyonlarının Güvenilirliği: Pilot Çalışma. Atatürk Üniv Diş Hek Fak Derg 2020; 30: 443-50.

Citation Information: Sahin SC. Reliability of Turkish Versions of Two Different Oral Health Indexes for Edentulous Geriatric Patients: A Pilot Study. $J$ Dent Fac Atatürk Uni 2020: 30: 443-50. 


\section{INTRODUCTION}

The population around the world is constantly aging and concerns regarding health-related quality of life (HRQoL) are increasing. By 2050, the number of people aged 60 years or over is expected to approach two billion. ${ }^{1}$ Meanwhile, in Turkey specifically, by 2023, the group of individuals 65 years or older is expected to total 8.6 million people (or $10.2 \%$ of the total population), ${ }^{2}$ and the majority of this population continues to struggle with oral health problems due to edentulism. ${ }^{2,3}$ Edentulism is a problem that can be solved with different prosthetic treatments today. However, patients' attitudes towards prosthetic treatments as a solution to edentulism may differ. ${ }^{4}$

Oral health has a critical effect on the daily activities of geriatric patients, which can affect functioning, cause pain, and have an impact on psychology and behavior. ${ }^{5}$ The acceptance of prosthetic treatments by geriatric patients requires functional and psychosocial adaptation processes that are highly influenced by these individuals' expectations. ${ }^{6}$ For this reason, the evaluation of oral health status is very important for determining the treatment needs and expectations of patients. However, using only objective clinical methods is not sufficient for determining which of these factors and special methods are required. ${ }^{4,5,7,8}$ For this purpose, oral HRQoL (QHRQoL) indexes have been developed. ${ }^{4,9}$

While numerous QHRQoL indexes have been developed in recent years, only some of them are frequently used in dentistry. ${ }^{5,10-12}$ The Oral Health Impact Profile (OHIP) was first implemented in 1994 by Slade and Spencer and includes 49 questions and seven subscales (i.e., functional limitation, psychological discomfort, physical pain, physical disability, social disability, psychological disability, and handicap). ${ }^{10}$ In 2003, Allen and Locker prepared a modified index known as the Oral Health Impact Profile for Edentulous (OHIP-EDENT), which included 19 questions and which is frequently used to understand on edentulous individuals today. ${ }^{9,13}$ Separately, the Geriatric Oral Health Assessment Index (GOHAI) was created in 1990 by Atchison and Dolan and first used in North America. ${ }^{11}$ This index consists of 12 questions and is comprehensive enough to measure a patient's oral functional problems and to assess issues such as physical, psychological, and social functioning as well as pain and discomfort. ${ }^{5,11}$
These indexes have been developed mainly in English and cannot be applied directly in Turkishspeaking groups because of the differences in linguistic, social, or economic structures and cultural characteristics. ${ }^{12,14}$ The applicability of such indexes in different countries is only possible with their translation according to the linguistic and cultural characteristics of the selected countries. ${ }^{5,12,14}$ In the last few years, Turkish versions of such indexes have been developed but, because of the number of studies boasting their involvement is few, available results are insufficient to reach definite conclusions about the indexes' usefulness. ${ }^{4,15-17}$ Also, to the best of our knowledge, in the literature there are no studies to test the Turkish version of such indexes in edentulous individuals. ${ }^{16,17}$ Therefore, this pilot study purposed to translate the GOHAI and OHIP-EDENT into Turkish, to determine their cross-cultural adaptation reliability among Turkish edentulous geriatric patients.

\section{MATERIALS AND METHODS}

The process of adapting the Turkish versions of the GOHAI and OHIP-EDENT for edentulous geriatric patients consisted of three main steps: the translation of the English version into Turkish, the conduct of the pilot study, and the completion of the main study for reliability and validity testing. However, this study is only concerned with the first two steps.

\section{Translation}

In this study, the GOHAI and OHIP-EDENT indexes were translated into Turkish. During the translation process, the correct formation of linguistic and cultural harmony was taken into consideration ${ }^{18,19}$ and the approach of Guillemin et al. ${ }^{20}$ was followed. According to this process, the indexes were first translated into Turkish by two independent translators. Then, these translations were backtranslated from Turkish to English by an English teacher and two prosthodontists who did not know the originals of the indexes who could speak both English and Turkish fluently. The translated and also backtranslated indexes were subsequently examined and compared in detail by two different prosthodontists who were experts in their field and who had extensive knowledge about $Q H R Q o L$ indexes. After these stages, the Turkish versions of the GOHAI (GOHAI-TR) and OHIP-EDENT (OHIP-ERDENT-TR) were obtained for use in an edentulous patient group. 


\section{Participants}

A total of 32 edentulous geriatric patients who applied to the Department of Prosthodontics of Pamukkale University Faculty of Dentistry and who used total prosthesis in both jaws were included in this pilot study. The study was confirmed by the noninterventional clinical research ethics commission of the Pamukkale University of Faculty of Medicine, Denizli, Turkey. All participants were informed about the study in writing and signed an informed consent form.

\section{Data collections}

Data collection involved the recording of demographic data such as general and clinical conditions (Table 1). The functional adaptation process (one month or longer) of the patients to be participants in the study was taken into consideration and patients were asked to answer each question of the indexes after this period. ${ }^{21}$ Application of the indexes was conducted by a prosthodontist (S.C.S) with face-to-face interviews. In the interview, a detailed information was given to the participants before they filled the questionnaire and they were able to consult the prosthodontist when they wanted to ask any questions. Two weeks after the first application, ${ }^{21}$ the participants were called in for the second application and the indexes were reapplied by the same prosthodontist. The obtained data from both applications were recorded for use in reliability analysis.

\section{Indexes}

The GOHAI consists of 12 questions about functional limitations, psychological and social condition, and symptoms related to dental health. The index does not include subscales in itself. The OHIPEDENT consists of 19 questions grouped according to seven subscales: functional limitation (items 1-3), physical pain (items 4-7), psychological discomfort (items 8 and 9), physical disability (items 10-12), psychological disability (items 13 and 14), social disability (items 15-17) and handicap (items 18 and 19). ${ }^{1,6,9,10}$

\section{Scoring}

There are five different scoring categories for each question in the indexes as follows: $1=$ always, 2 = often, $3=$ sometimes, $4=$ seldom, and $5=$ never. The indexes included both positive and negative questions and the scores from the positive questions were reversed during data processing to ensure that all responses had the same orientation. ${ }^{4}$
Table 1. Distribution of the assessment of oral health condition of the patients

\begin{tabular}{|c|c|c|c|}
\hline \multicolumn{2}{|c|}{ PATIENT CONDITION } & \multicolumn{2}{|c|}{$\begin{array}{c}\text { VARIABLE } \\
\mathbf{S}\end{array}$} \\
\hline & & $\mathbf{n}$ & $\%$ \\
\hline \multirow[b]{2}{*}{ Gender } & Male & 13 & 40.6 \\
\hline & Female & 19 & 59.4 \\
\hline \multirow{3}{*}{ Age in Years } & 65 & 15 & 46.8 \\
\hline & $65-74$ & 12 & 37.5 \\
\hline & $>75$ & 5 & 15.6 \\
\hline \multirow{2}{*}{ Marital Status } & Married & 27 & 84.3 \\
\hline & Single & 5 & 15.7 \\
\hline \multirow{6}{*}{ Education } & Literate & 6 & 18.7 \\
\hline & Primary school & 14 & 43.7 \\
\hline & Middle school & 3 & 9.3 \\
\hline & High school & 4 & 12.5 \\
\hline & University & 4 & 12.5 \\
\hline & Master & 1 & 3.1 \\
\hline \multirow{9}{*}{ Occupation } & Retired & 6 & 18.7 \\
\hline & Teacher & 3 & 9.3 \\
\hline & Farmer & 2 & 6.2 \\
\hline & Technician & 1 & 3.1 \\
\hline & Housewife & 15 & 46.8 \\
\hline & Driver & 1 & 3.1 \\
\hline & Blacksmith & 1 & 3.1 \\
\hline & Chef & 1 & 3.1 \\
\hline & Workman & 2 & 6.2 \\
\hline \multirow{2}{*}{ Accommodation } & with Family & 28 & 87.5 \\
\hline & Single & 4 & 12.5 \\
\hline \multirow{2}{*}{ Smoking } & Yes & 11 & 34.3 \\
\hline & No & 21 & 65.6 \\
\hline \multirow{8}{*}{$\begin{array}{l}\text { General Health } \\
\text { Status }\end{array}$} & Cardiovascular diseases & 5 & 15.7 \\
\hline & Neurological disease & 1 & 3.1 \\
\hline & Psychiatric disease & 1 & 3.1 \\
\hline & Diabetes & 1 & 3.1 \\
\hline & Hypertension & 4 & 12.4 \\
\hline & Osteoporosis & 1 & 3.1 \\
\hline & Chronic Obstructive & 2 & 6.2 \\
\hline & $\begin{array}{l}\text { Pulmonary Disease } \\
\text { No disease }\end{array}$ & 17 & 53.1 \\
\hline \multirow{2}{*}{$\begin{array}{l}\text { Frequency of } \\
\text { Dental Visits }\end{array}$} & Every 6 months & 14 & 43.7 \\
\hline & $>6$ months & 18 & 56.2 \\
\hline \multirow{3}{*}{$\begin{array}{l}\text { Frequency of } \\
\text { Brushing Teeth }\end{array}$} & Sometimes & 18 & 56.2 \\
\hline & Always & 10 & 31.2 \\
\hline & Newer & 4 & 12.5 \\
\hline \multirow{2}{*}{$\begin{array}{l}\text { Presence of Dry } \\
\text { Mouth }\end{array}$} & Yes & 10 & 31.2 \\
\hline & No & 22 & 68.7 \\
\hline Dental Status & Total Prosthesis in both Jaw & 32 & 100 \\
\hline
\end{tabular}

The total score of GOHAI and OHIP-EDENT is the sum of the answers given for all questions in the indexes, with high scores (60 and 95 points, respectively) indicating satisfactory oral health. There is no agreed-upon score range in the literature for either index suggesting good or poor oral health, but as the results of the indexes approach their maximum values, the level of satisfaction of the respondents about their oral health increases.

\section{Data analysis}

In order to develop the GOHAI-TR and OHIPEDENT-TR, firstly, a pool of items was established and expert opinions were obtained. The internal consistency of the indexes was evaluated by Cronbach's $\alpha$ calculation and item total correlation coefficients. ${ }^{6}$ Also the test-retest reliability was determined using data from 32 participants who answered the indexes at two-week intervals. ${ }^{22}$ In the evaluation of these indexes used in the pilot study, the original reliability studies of the indexes were taken as a basis. ${ }^{10,11}$ 
The internal consistency of the subscales for the OHIP-EDENT index was found to have excellent reliability if Cronbach's $\alpha$ value was between 0.70 or greater. Further, the test-retest reliability was also accepted as stable in the intraclass correlation (ICC) if the correlation coefficient was between 0.42 and 0.77 . ICC values less than 0.40 were considered to show poor agreement, while moderate agreement was achieved in the 0.41 and 0.60 range, good agreement was achieved in the 0.61 and 0.80 range, and excellent agreement was achieved if the results were more than $0.80 .^{10}$

In GOHAI, the internal consistency of the index when Cronbach's a > 0.75 indicated excellent internal reliability, whereas values of between 0.40 and 0.75 suggested fair to good reliability and values of $<0.40$ indicated poor reliability of the scale. ${ }^{11}$

In addition to the reliability analyses, the reproducibility of the indexes was examined. The reproducibility analysis includes a test of agreement between the two proposed applications of the indexes. In this pilot study, the consistency of the answers given at two different application times and the total scores were compared and it was determined whether a statistical difference existed between the results of the applications for both indexes by using a dependent t-test. All data were analyzed using the SPSS software version 23.0 for windows (IBM Corp., Armonk, NY, USA).

\section{RESULTS}

\section{Population characteristics}

In total, 32 patients were participated in the pilot study, with all patient presenting with total prostheses in both jaws. The majority of patients were between the ages of 65 to 74 years $(84.3 \%)$ and female (59.4\%). Most patients were married (84.3\%) and just over half (53\%) of the participants did not have any systemic disorders. Most of the participants stated that they had not been examined by a dentist for more than six months (56.2\%).

\section{Linguistic translation}

According to the face-to-face interviews, it was necessary to modify the linguistic translation of some questions of the indexes to make them more understandable. Thus, GOHAI item-3 was changed from "how often were you able to swallow comfortably?" to "how often were you unable to swallow comfortably?"; GOHAI item-5 was changed from "how often were you able to eat anything without feeling discomfort?" to "how often do you feel that you unable to eat anything comfortably?"; and GOHAI item-7 was changed from "how often were you pleased or happy with the looks of your teeth, gums and dentures?" to "how often were you unpleased or unhappy with the looks of your teeth, gums and dentures?." For the OHIP-EDENT item-2 was changed from "have you had food catching in your teeth or dentures?" to "have you had failure about catching food in your teeth or dentures?." The other questions in the indexes were used in their original form.

Reliability of the GOHAI-TR and OHIP-

\section{EDENT-TR}

Frequency and percentage distributions, mean and standard deviation (SD) values of the items in the GOHAI-TR are presented in Table 2. In total, 50\% of participants answered "always" to GOHAI item-6 (mean: 3.97, SD: 1.28) and GOHAI item-8 (mean: 4.16, SD: 1.05). For GOHAI item-10, $46.9 \%$ of participants answered "always" (mean: 3.84, SD: 1.22). For GOHAI item-7 and item-11, $37.5 \%$ of the participants felt that these were "always" problems (mean: 3.47, SD: 1.52 and mean: 3.5, SD: 1.48, respectively). Although $34.4 \%$ of participants reported that they "always" had problems speak clearly (GOHAI item-4; mean: 3.54, SD: 1.5). The majority of the participants reported that they "sometimes" had problems regarding GOHAI item-1 and item-3. Also, it was determined that $31.1 \%$ of the participants never had trouble in biting and chewing (GOHAI item-2; mean: 2.38, SD: 1.26).

Internal consistency of the GOHAI-TR was evaluated with Cronbach's $\alpha$ coefficient and it was obtained as 0.897 that well above the critical values $(\alpha<0.79$ ). According to this value, GOHAI-TR can be considered as a scale with excellent reliability and homogeneity. If any of the 12-items are deleted, the change in Cronbach's $\alpha$ of the index is presented in Table 3. Accordingly, it was observed that no item was required to be deleted.

In this study, the GOHAI-TR was administered to participants at two-week intervals and the data obtained from both weeks were recorded. The average values of the results obtained with the participants in the first and second application were 39.84 and 39.94, respectively. The reproducibility of the GOHAI-TR was confirmed with a Pearson correlation coefficient of 0.992 and a positive-direction and strong statistically significant relationship $(r=$ 
0.992; $\mathrm{p}<0.001$ ) was detected. According to the dependent t-test, there was no statistical difference between the mean values of the applications ( $p=$ 0.712) (Table 4).

Table 2. Frequency and percentage (\%) distributions and mean and standard deviation (SD) values of the items in GOHAI-Turkish (GOHAI-TR)

\begin{tabular}{|c|c|c|c|c|c|c|c|}
\hline \multicolumn{2}{|c|}{ GOHAL-TR I tenes } & \multirow{2}{*}{$\begin{array}{l}\text { never } \\
0\{10.5\}\end{array}$} & \multirow{2}{*}{$\begin{array}{l}\text { Setten } \\
4(1.5)\end{array}$} & \multirow{2}{*}{$\begin{array}{l}\text { Sometimes } \\
17(40,4)\end{array}$} & \multirow{2}{*}{$\frac{\text { Often }}{5(19.6)}$} & \multirow{2}{*}{$\begin{array}{l}\text { Aways } \\
4(12.5)\end{array}$} & \multirow{2}{*}{$\begin{array}{l}\text { Mevan }+50 \\
291=179\end{array}$} \\
\hline $\begin{array}{l}\text { GOHAA } \\
\text { ittan-1. }\end{array}$ & $\begin{array}{l}\text { Imenting the kinds of } \\
\text { sood }\end{array}$ & & & & & & \\
\hline $\begin{array}{l}\text { G0HAd } \\
\text { iten=2 }\end{array}$ & 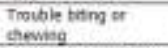 & $10(3.2)$ & $=(25)$ & $9(24.1)$ & $2(5.2)$ & $3(9.4)$ & $2.29+1.28$ \\
\hline $\begin{array}{l}\text { 60\% N } \\
\text { itean }=3\end{array}$ & $\begin{array}{l}\text { Prablents to suntiow } \\
\text { camflotidsy }\end{array}$ & ' (25) & $\pm(28)$ & $9(28.1)$ & $2(0,4)$ & $4(12.5)$ & $2.59 \div 137$ \\
\hline $\begin{array}{l}\text { GoHNN } \\
\text { itan } 4\end{array}$ & $\begin{array}{l}\text { Protiens to spent } \\
\text { deaty }\end{array}$ & $6(15.8)$ & $2(4.7)$ & $4(12.5)$ & $0(2 a ; t)$ & $\mathrm{II}(34.4)$ & $3.53=1.50$ \\
\hline $\begin{array}{l}\operatorname{cosin} t \\
\text { itan-5 }\end{array}$ & 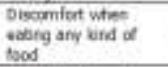 & $7(21.5)$ & $6(19.8)$ & $4(25)$ & $2(6.2)$ & $3(28.1)$ & $3.00=1.12$ \\
\hline $\begin{array}{l}\text { Gond } \\
\text { itan-6 }\end{array}$ & $\begin{array}{l}\text { Imin contad with } \\
\text { geopir }\end{array}$ & $2(6.2)$ & $3(2.4)$ & $S(15.6)$ & $6(18.8)$ & $26(50)\}$ & $3.97=1.28$ \\
\hline $\begin{array}{l}\text { GotA } \\
\text { itan } \rightarrow 7\end{array}$ & $\begin{array}{l}\text { Urplessant wath lock } \\
\text { of toesh }\end{array}$ & 3.5) & 4 & y) & 6) & 5) & 52 \\
\hline $\begin{array}{l}\cos \pi / 4 \\
\text { itan- } 8\end{array}$ & $\begin{array}{l}\text { Uned macation to } \\
\text { refiove pan }\end{array}$ & $1(3.1)$ & $1(3.1)$ & $6(18.8)$ & $8(25)$ & $26(50))$ & $4.16=1.05$ \\
\hline $\begin{array}{l}\text { 60AAI } \\
\text { item } \rightarrow 9\end{array}$ & $\begin{array}{l}\text { Womed atout beath, } \\
\text { gume or derbires }\end{array}$ & $5\{15.6\}$ & $3(8.4)$ & 15) & 1.5) & 6) & 26 \\
\hline $\begin{array}{l}\text { 60HAI } \\
\text { iten-10 }\end{array}$ & 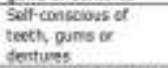 & $1(3.1)$ & $3(9.4)$ & $11(34,4)$ & $2\{6.2\}$ & $15(46,9)$ & $3.64=1.22$ \\
\hline $\begin{array}{l}\text { 60MAI } \\
\text { ittem-11 }\end{array}$ & $\begin{array}{l}\text { Unoomfontable exing } \\
\text { in frent of chthers? }\end{array}$ & $4(12.5)$ & 98 & 12.5) & 68 & $12(37.5)$ & 1.50 \\
\hline $\begin{array}{l}\text { G0MAI } \\
\text { item-12 }\end{array}$ & $\begin{array}{l}\text { Senstive to hot, wid } \\
\text { of weet fopds }\end{array}$ & $4(12,5)$ & $3(9,4)$ & $11:(34,-4)$ & $5(156)$ & $9(28.1)$ & $1,39=1,34$ \\
\hline
\end{tabular}

Table 3. Cronbach's alpha reliability analysis results for GOHAI-TR

\begin{tabular}{|c|c|c|c|}
\hline GOHAI-TR & $\begin{array}{l}\text { Index average if } \\
\text { item deleted }\end{array}$ & $\begin{array}{l}\text { Corrected item-total } \\
\text { correlation }\end{array}$ & $\begin{array}{c}\text { Cronbach's } \\
\text { alpha if item } \\
\text { deleted }\end{array}$ \\
\hline $\begin{array}{l}\text { GOHAI } \\
\text { item-1 } \\
\text { GOHAI }\end{array}$ & 36.938 & 0.793 & 0.880 \\
\hline $\begin{array}{l}\text { item-2 } \\
\text { GOHAI }\end{array}$ & 37.469 & 0.562 & 0.891 \\
\hline $\begin{array}{l}\text { item-3 } \\
\text { GOHAI }\end{array}$ & 37.250 & 0.641 & 0.888 \\
\hline $\begin{array}{l}\text { item-4 } \\
\text { GOHAI }\end{array}$ & 36.313 & 0.794 & 0.878 \\
\hline $\begin{array}{l}\text { item-5 } \\
\text { GOHAI }\end{array}$ & 36.844 & 0.489 & 0.896 \\
\hline $\begin{array}{l}\text { item-6 } \\
\text { GOHAI }\end{array}$ & 35.875 & 0.787 & 0.880 \\
\hline item-7 & 36.375 & 0.459 & 0.898 \\
\hline $\begin{array}{l}\text { item-8 } \\
\text { GOHAI }\end{array}$ & 35.688 & 0.433 & 0.897 \\
\hline $\begin{array}{l}\text { item-9 } \\
\text { GOHAI }\end{array}$ & 36.719 & 0.525 & 0.893 \\
\hline $\begin{array}{l}\text { item-10 } \\
\text { GOHAI }\end{array}$ & 36.000 & 0.847 & 0.878 \\
\hline $\begin{array}{l}\text { item-11 } \\
\text { GOHAI }\end{array}$ & 36.344 & 0.661 & 0.886 \\
\hline item-12 & 36.469 & 0.435 & 0.898 \\
\hline
\end{tabular}

Table 4. Analysis results of first and second application of GOHAI-TR and OHIP-EDENT-TR

\begin{tabular}{|c|c|c|c|c|}
\hline & Apdicaton Time & $\operatorname{Mean} \pm S 0$ & Condetion & $p^{*}$ \\
\hline \multirow{2}{*}{ GOHAI-TR } & Finstapplication & $3.94=11.24$ & \multirow{2}{*}{0.992} & \multirow{2}{*}{0712} \\
\hline & Second application & $3.94=1 \mathrm{L15}$ & & \\
\hline OHIP-EOENT-TR & $\begin{array}{l}\text { Fint appliction } \\
\text { Second application }\end{array}$ & $\begin{array}{l}60.50=17.9 \\
60.25=17.93\end{array}$ & 0.988 & 0618 \\
\hline
\end{tabular}

*Dependent sample $t$ test.

The frequency and percentage distributions, mean and SD values of the OHIP-EDENT-TR index are presented in Table 5. The mean values of the scale items ranged between $2.50 \pm 1.22$ and $4.38 \pm 1.01$. The lowest mean value was obtained for OHIP-EDENT item-1 and the highest mean value was obtained for OHIP-EDENT item-18. Our analysis also showed that the most serious problems of the participants pertained to psychological discomfort, social disability, psychological disability, and handicap.

Table 5. Frequency and percentage (\%) distributions and mean and standard deviation (SD) values of the items in OHIP-EDENT-TR

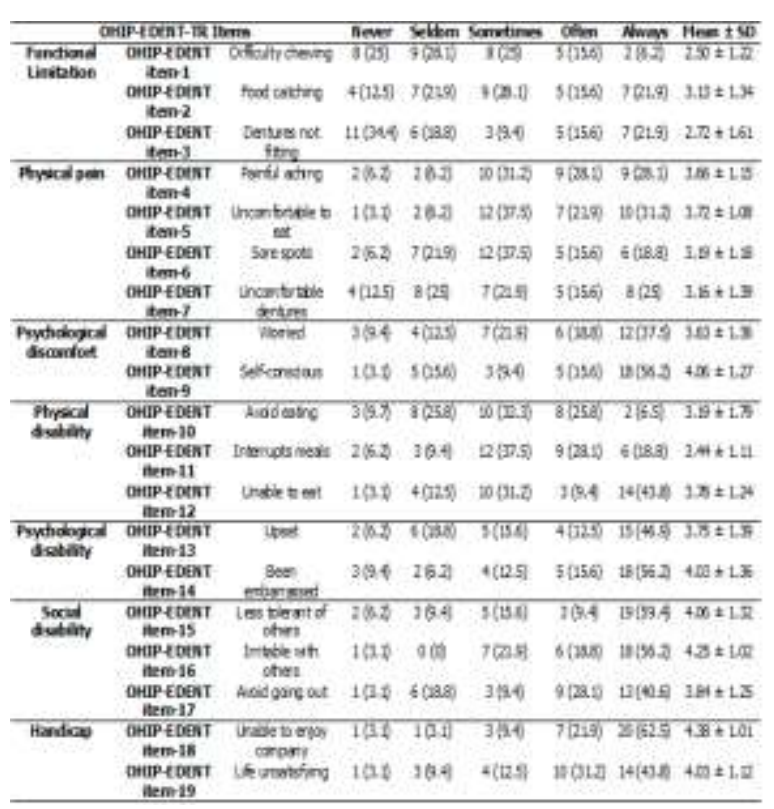

$62.5 \%$ and $59.4 \%$ of participants answered "always" for OHIP-EDENT item-18 (mean: 4.38, SD: 1.01) and OHIP-EDENT item-15 (mean: 4.06, SD: 1.32), respectively. For OHIP-EDENT item-9 and item$14,56.2 \%$ of the participants felt that these were "always" problems (mean: 4.06, SD: 1.27 and mean: 4.03, SD: 1.36 , respectively). Also, $46.9 \%$ of participants reported that they "always" felt upset (OHIP-EDENT item-13, mean: 3.75, SD: 1.39). For OHIP-EDENT item-12 and item-19, $43.8 \%$ of participants answered these are "always" (mean: 3.78, SD: 1.24 and mean: 4.03, SD: 1.12, respectively) problems. Although most of the participants reported that they "always" had emotional, social, and physical problems. The majority of participants reported that they "sometimes" had problems in response to OHIPEDENT item-2, item-5, and item-6. For OHIP-EDENT item-1 that asked about chewing difficulties, $28.1 \%$ of 
participants responded "seldom." Also, it was determined that $34.4 \%$ of the participants never had trouble in fitting their dentures (OHIP-EDENT item-3; mean: 2.72, SD: 1.61).

Cronbach's $\alpha$ of the OHIP-EDENT-TR was 0.947 , suggesting excellent reliability. When any of the 19-items were deleted, the change in Cronbach's $\alpha$ of the index was as seen in Table 6 . Accordingly, it was observed that no item was required to be deleted. Upon deleting an item from the scale, the average value of the scale and the total correlation values of the item are as presented in Table 6 .

There are seven subscales of the OHIP-EDENT scale. Table 7 shows the internal consistency of the subscales. Total Cronbach's alpha score of OHIPEDENT-TR was 0.947, and values for the subscales varied 0.665 for "psychological discomfort" to 0.883 for "psychological disability." The lowest Cronbach's $\alpha$ was obtained in the "psychological discomfort" subscale.

Test-retest reliability was computed for all participants and $95 \%$ confidence intervals of the means were calculated. The total ICC score of OHIPEDENT-TR was 0.967, and scores for the subscales varied 0.665 (95\% CI: $0.314-0.837$ ) to 0.883 (95\% CI: 0.761-0.943), indicating good to excellent consistency. When the ICC coefficient and test-retest reliability were examined, though the correlation values obtained in the "psychological discomfort" subscale were good, strong positive correlations were obtained in all other subscales (Table 7). These results showed high reliability for the OHIP-EDENT-TR.

In this study, the OHIP-EDENT-TR was administered to participants at two-week intervals and the data obtained from both weeks were recorded. The average values of the results obtained with the participants in the first and second application were 68.50 and 68.25 , respectively. The reproducibility of the OHIP-EDENT-TR was confirmed with a Pearson correlation coefficient of 0.988 and a positive-direction and strong statistically significant relationship ( $r=$ 0.988; $p<0.001$ ) was detected. According to the dependent t-test, there was no statistical difference between the mean values obtained during the two application ( $p=0.618$ ) (Table 4).

\section{DISCUSSION}

This study was conducted to measure the GOHAI-TR and OHIP-EDENT-TR among institutionalized edentulous patients in Turkey. Most of the
QHRQoL indexes used today are generated in English ${ }^{12,14}$ and, as the focus on QHRQoL has increased recently, a need for cultural adaptation has grown to facilitate the adoption of the original questionnaires. ${ }^{20}$ Although some studies have evaluated OHRQoL in different patient groups in recent years, ${ }^{4,15,16}$ Turkish versions of the patientspecific OHRQoL measure for edentulous patients are needed.

Further, the linguistic translations of the indexes must then be tested in pilot studies. In particular, it is very valuable to examine the internal consistency of the questionnaire, the difficulties of interpreting at the cultural level, and the ability of the patients to understand and also answer the questions in a pilot study. Based on the results of such a pilot study, planning additional main studies and applying them in specific patient groups together constitutes the most scientifically correct application process. Because during the pilot phase, the first version of the questionnaire can be modified, any points that are misunderstood by patients caused by inappropriate linguistic translation can be identified and corrected and the questions can be rearranged. Thus, the data in the main study can be obtained in a more accurate and understandable way. ${ }^{5,8}$

Translating questionnaires on QHRQoL into different language is the most critical stage in the cross-cultural adaptation of these kinds of questionnaires. $^{13,18,19}$ In this study, linguistic translations for cultural and conceptual equivalence and intercultural adaptation were conducted according to the protocol reported by Guillemin et al. ${ }^{20}$ However, in order to make the questionnaires more understandable, three questions in the GOHAI (items 3,5 and 7) and one question in the OHIP-EDENT (item 2) had to be modified.

It is important that the scale is confirmed to have sufficient internal consistency and reliability for further studies because only scales exhibiting high internal consistency and reliability are considered to be usable in a representative patient group for the main study. 8 Therefore, our pilot study involved a cross-cultural adaptation of the GOHAI and OHIPEDENT indexes and determine the reliability of both according to international studies. ${ }^{4-6,9,13,17}$ Our study results promote the reliability of the GOHAI-TR and OHIP-EDENT-TR indexes among Turkish people and also the linguistic and cultural accompaniment of the Turkish and English versions of these questionnaires. 
The threshold values for Cronbach's $\alpha$ for GOHAI and OHIP-EDENT in the literature were 0.75 and 0.70. All Cronbach's $\alpha$ data obtained from our study were above these threshold values and our values were higher than those obtained with the applied Chinese, Malayalam, Brazilian, and Romanian versions. $5,6,8,13$ This change can be perceived to indicate that Cronbach's $\alpha$ will be affected by sample size even if only partially. There is no sample size or power calculation for test-retest analysis. However, according to a general rule adopted in this context, a sample group of 25 to 50 patients is considered sufficient for data analysis. ${ }^{23}$ In this current study, a reliability analysis was performed involving 32 participants, which is lower than that in similar studies. Therefore, the internal consistency and reliability coefficients may be found to be positively higher than those in other studies. Also, the corrected item-total correlations obtained in this study were well above the recommended levels in the literature for GOHAI and OHIP-EDENT. 4,5,8,13 These results indicate that both GOHAI-TR and OHIP-EDENT-TR have good internal consistency and reliability.

To assess the test-retest reliability, it is generally recommended that the interval between recurrent applications be long enough to avoid recall but also short enough to avoid clinical alterations. A definite time interval was not determined experimentally, but a one- or two-week period is often considered appropriate. ${ }^{22}$ Therefore, in the present study, it was found appropriate to maintain a twoweek period between the first and second questionnaires. Test-retest reliability analysis for GOHAI-TR, OHIP-EDENT-TR, and OHIP-EDENT'S subscales have shown that all are reliable and stable indices.

In many studies on the subject of QHRQoL in the elderly population, it was found that the participants always had problems especially in the area of functional limitations due to edentulousness, a lack of teeth, or incomplete and inadequate prosthetic treatments. $^{4-6,8}$ Similarly, in our study, although our participants consisted of edentulous individuals, we found that they were more significantly affected by psychological and social integration rather than functional issues in both indexes. It should be said that these findings are more surprising than those of studies in which indexes are applied in different populations. ${ }^{5,6,8}$ These findings mean that oral health changes due to edentulousness have a negative effect on QoL in terms of psychological and social relations in Turkish society, unlike in other societies. On the other hand, edentulous individuals may have responded to the questionnaires without emphasizing these problems, assuming that functional problems after prosthetic treatments are a normal process for individuals using complete dentures to experience. ${ }^{5}$ Therefore, there may be an artificial increase in the total scores of psychological and social disorders according to functional problems.

This study has several limitations in that other factors such as the time of loss of teeth, the condition of upper and lower jaw relations, and bone resorption level should also be considered. The main study should be conducted using a larger sample group and taking into account all of these factors.

\section{CONCLUSION}

This pilot study is important in that it is the first time the Turkish versions of GOHAI and OHIP-EDENT indexes in edentulous patients were evaluated. Study results showed acceptable cultural adaptation, reliability, and stability of the GOHAI-TR and OHIPEDENT-TR. The Turkish versions of both indexes seem to provide valuable information about oral health conditions as well as psychological and functional problems in geriatric edentulous persons. The results ensure first proof that both the GOHAI-TR and OHIPEDENT-TR may be beneficial tools for evaluating patient satisfaction concerning the use of complete dentures in Turkey.

\section{ACKNOWLEDGEMENTS}

The authors received no financial support for the research, authorship and/or publication of this article. The authors declare that they have no competing interests.

\section{REFERENCES}

1. Liu N, Zeng L, Li Z, Wang J. Health-related quality of life and long-term care needs among elderly individuals living alone: a cross-sectional study in rural areas of Shaanxi Province, China. BMC Public Health 2013; 8:313-9.

2. Türkiye İstatistik Kurumu Nüfus Projeksiyonları, 2013-2075. Sayı:15844. [Internet] Available from: http://www.tuik.gov.tr/PreHaberBultenleri.do?id=1 $5844 \& \mathrm{v}=1362363 \quad 401000 ? \mathrm{v}=1362363401000$. Accessed:10.12.2019. 
3. Büyükkaplan Ş, Güldağ MÜ, Tuna SH, Turna Ç. Tam Dişsiz kadın ve erkek bireylerde alt çene alveolar residüel kret rezorpsiyonlarının karşılaştırılması. Atatürk Üniv Dis Hek Fak Derg 2012;1:46-21.

4. Ergül S, Akar GC. Reliability and validity of the Geriatric Oral Health Assessment Index in Turkey. J Gerontol Nurs 2008; 34:33-9.

5. Shekhawat K, Chauhan A, Koshy A, Rekha P, Kumar $H$. Reliability of Malayalam version of Geriatric Oral Health Assessment Index among institutionalized elderly in Alleppey, Kerala (India): A pilot study. Contemp Clin Dent 2016;7:153-7.

6. Souza RF, Patrocínio L, Pero AC, Marra J, Compagnoni MA. Reliability and validation of a Brazilian version of the Oral Health Impact Profile for assessing edentulous subjects. J Oral Rehabil 2007;34:821-6.

7. Slade GD, Strauss RP, Atchison KA, Kressin NR, Locker D, Reisine ST. Conference summary: assessing oral health outcomes-measuring health status and quality of life. Community Dent Health 1998;15:3-7.

8. Murariu A, Hanganu C, Bobu L. Evaluation of the Reliability of the Geriatric Oral Health Assessment Index (GOHAI) in Institutionalized Elderly in Romania: A Pilot Study. OHDMBSC 2010; 9:11-5. [Internet] Available From: https://www. semanticscholar.org/paper/Evaluation-of-theReliability-of-the-Geriatric-Oral-Murariu-Hanganu/ b3de97bae05b34f7cd0c7e11752ee26ee04f5832. Accessed: 05.05.2020.

9. Allen F, Locker D. A modified short version of the oral health impact profile for assessing healthrelated quality of life in edentulous adults. Int J Prosthodont 2002;15:446-50.

10. Slade GD, Spencer AJ. Development and evaluation of the Oral Health Impact Profile. Community Dent Health 1994;11:3-11.

11. Atchison KA, Dolan TA. Development of the Geriatric Oral Health Assessment Index. J Dent Educ 1990;54:680-7.

12. Parthasarathy DS, McGrath CPJ, Bridges SM, Wong HM, Yiu CKY, Au TKF. Efficacy of instruments measuring oral health literacy: a systematic review. Oral HIth Prev Dent 2014;12:201-7.

13. He SL, Wang JH. Reliability and validity of a Chinese version of the Oral Health Impact Profile for edentulous subjects. Qual Life Res 2015;24:1011-6.
14. Horowitz AM, Kleinman D V. Oral Health Literacy: The New Imperative to Better Oral Health. Dent Clin North Am 2008;52:333-44.

15. Gokturk O, Yarkac FU. Assessment of oral healthrelated quality of life among elderly patients with periodontal disease. Turk J Geriatr 2018; 21:31322.

16. Peker K, Köse TE, Güray B, Uysal Ö, Erdem TL. Reliability and validity of the Turkish version of the Rapid Estimate of Adult Literacy in Dentistry (TREALD-30). Acta Odontol Scand 2017;75:198207.

17. Balci N, Alkan N, Gurgan CA. Psychometric properties of a Turkish version of the oral health impact profile-14. Niger J Clin Pract 2017;20:1924.

18. Herdman M, Fox-Rushby J, Badia X. A model of equivalence in the cultural adaptation of HRQoL instruments: the universalist approach. Qual Life Res 1998;7:323-35.

19. Sullivan M. Cross-cultural validation for quality of life. J Clin Epidemiol 1994;47:1465-6.

20. Guillemin F, Bombardier C, Beaton D. Crosscultural adaptation of health-related quality of life measures: Literature review and proposed guidelines. J Clin Epidemiol 1993;46:1417-32.

21. Leles CR, Compagnoni MA, de Souza RF, Barbosa DB. Kinesiographic study of mandibular movements during functional adaptation to complete dentures. J Appl Oral 2003;11:311-8.

22. Terwee CB, Bot SDM, de Boer MR, van der Windt DAWM, Knol DL, Dekker J, et al. Quality criteria were proposed for measurement properties of health status questionnaires. J Clin Epidemiol 2007;60:34-42.

23. Anthoine $E$, Moret $L$, Regnault A, Sbille V, Hardouin JB. Sample size used to validate a scale: A review of publications on newly-developed patient reported outcomes measures. Health Qual Life Out 2014;9:176-85.
Yazışma Adresi
Sezgi Cinel Sahin
Department of Prosthodontics, Faculty of
Dentistry, Pamukkale University
Camlaraltı Mahallesi, Suleyman Demirel Cd.
No:95, Post Code:20160, Pamukkale, Denzili
Tel +90 5058996237,
Fax +90 2582961763
e-mail.sezgis@pau.edu.tr 